\title{
THE ANTIDIPHTHERIA ANTIBODIES OF SEROEPIDEMIOLOGY SURVEY AMONG ADOLESCENTS IN BANGKALAN AND KEDIRI DISTRICTS
}

\section{Survei Seroepidemiologi Antibodi Antidifteri Pada Remaja di Kabupaten Bangkalan dan Kediri}

\author{
Dominicus Husada ${ }^{1,2} \mathbb{D}$, Kristina Marbun ${ }^{1,2}$, Desy Primayani ${ }^{1,2}$, Leny Kartina ${ }^{1,2} \mathbb{D}$, Dwiyanti \\ Puspitasari $^{1,2} \mathbb{D}^{D}$, Parwati S. Basuki ${ }^{1,2}$, Ismoedijanto Ismoedijanto ${ }^{1,2}{ }^{\infty}$, Aris Widji Utami ${ }^{3}$, Eveline \\ Irawan $^{3}$ \\ ${ }^{1}$ Department of Child Health, Faculty of Medicine, Universitas Airlangga, Surabaya 60132, Indonesia, \\ dominicushusada@yahoo.com \\ ${ }^{2}$ Dr. Soetomo Hospital Surabaya, Surabaya 60286, Indonesia dominicushusada@yahoo.com \\ ${ }^{3}$ Central Health Laboratory (BBLK) Surabaya, Surabaya 60286, Indonesia, dominicushusada@yahoo.com \\ Corresponding Author: Dominicus Husada, dominicushusada@yahoo.com, Department of Child Health, \\ Faculty of Medicine, Universitas Airlangga/Dr. Soetomo Hospital, Surabaya 60286, Indonesia
}

\section{ARTICLE INFO \\ Article History: \\ Received April, $8^{\text {th }}, 2019$ \\ Revised form May, 31 3019 \\ Accepted August, 29 $9^{\text {th }}, 2019$ \\ Published online August, 30 $0^{\text {th }}, 2019$}

\section{Keywords:}

seroepidemiology survey; antidiphtheria antibody;

adolescents;

east java

\section{Kata Kunci:}

survei seroepidemiologi,

antibodi antidifteri;

remaja;

jawa timur

\begin{abstract}
Background: An increase in diphtheria cases has occurred in East Java Province since 2011. The resistance level to diphtheria is considered as the most important cause. Purpose: The study aims analyzed the immunity level immunity to diphtheria in adolescents aged 16-18 years old in Bangkalan and Kediri Districts. Methods: This study was a cross sectional study, conducted on students in eleven grade of senior high schools (SMAN) from both districts. The inclusion criteria included being 16-18 years old and students in eleven grades of senior high schools in Bangkalan and Kediri. This study was approved by their parents/guardians. The exclusion criteria included immunocompromised students and those who have a history of diphtheria infection. The data were obtained from 204 samples, 89 samples in Bangkalan, and 115 samples in Kediri. The antidiphtheria antibodies examination was carried out by the Vero cell method. The antibodies levels were grouped according to WHO standard, consist of vulnerable, basic, full, and long-term. Further analysis was done with 2 tiers of immunity, consist of immune and vulnerable. Results: The immunization coverage for basic and booster diphtheria vaccine is better in Kediri than in Bangkalan. In contrast, levels of antibodies samples in Bangkalan District is better. The participants who were immune in Bangkalan were higher than those in Kediri $(91 \%$ vs. $44.30 \%$ ). Conclusion: The immunity adolescents of Bangkalan is higher than in adolescent Kediri District. The adolescents in Kediri have a greater risk to get infected by the disease.
\end{abstract}

C2019 Jurnal Berkala Epidemiologi. Published by Universitas Airlangga. This is an open access article under CC BY-SA license

\section{ABSTRAK}

Latar Belakang: Peningkatan kasus difteri terjadi di Provinsi Jawa Timur terutama sejak tahun 2011. Tingkat kekebalan terhadap penyakit difteri merupakan salah satu penyebab utama. Tujuan: Penelitian ini bertujuan untuk mengetahui kadar antibodi antidifteri 
How to Cite: Husada, D., Marbun, K., Primayani, D., Kartina, L., Puspitasari, D., Basuki, P. S., ... \& Irawan, E. (2019). The antidiphtheria antibodies of seroepidemiology survey among adolescents in Bangkalan and Kediri districts. Jurnal Berkala Epidemiologi, 7(2), 94-102. https://dx.doi.org/10.20473/jbe.v7i2 2019. 94-102 yang menunjukkan tingkat kekebalan terhadap penyakit difteri pada anak usia 16-18 tahun di Kabupaten Bangkalan dan Kediri. Metode: Penelitian ini cross sectional yang dilakukan pada partisipan yang berasal dari siswa kelas XI Sekolah Menengah Atas Negeri (SMAN) di Kabupaten Bangkalan dan Kediri. Kriteria inklusi meliputi usia 16-18 tahun, siswa kelas XI SMAN, dan disetujui oleh orang tua/wali. Kriteria eksklusi dalam penelitian ini adalah siswa dengan kondisi imunokompromais dan dengan riwayat menderita difteri sebelumnya. Pengambilan sampel menggunakan teknik sampel acak sederhana dengan total sampel yaitu 204 sampel (89 di Bangkalan dan 115 di Kediri). Pemeriksaan antibodi antidifteri dilakukan dengan metode vero cell. Kadar antibodi dikelompokkan sesuai standar WHO menjadi 4 yaitu susceptible, basic, full, dan long term. Analisis lanjutan juga dilakukan dengan membagi kadar antibodi tersebut menjadi 2 yaitu relatif kebal dan rentan. Hasil: Cakupan imunisasi difteri dasar dan ulangan lebih banyak di Kabupaten Kediri dibandingkan Bangkalan. Kadar antibodi antidifteri pada sampel di Kabupaten Bangkalan lebih baik. Responden yang memiliki kekebalan terhadap penyakit difteri lebih banyak di Bangkalan daripada di Kediri (91\% vs 44,30\%). Kesimpulan: Remaja yang memiliki kekebalan terhadap penyakit difteri lebih banyak di Bangkalan dibandingkan Kabupaten Kediri. Remaja Kediri mempunyai risiko terkena difteri yang lebih besar.

C2019 Jurnal Berkala Epidemiologi. Penerbit Universitas Airlangga. Jurnal ini dapat diakses secara terbuka dan memiliki lisensi CC BY-SA

\section{INTRODUCTION}

Diphtheria is one of the most lethal infectious diseases in the world, especially in the pre-vaccine era (Husada et al., 2018). The etiology of this disease is corynebacterium diphtheriae. There are two others bacteria as the primary cause especially in the developed countries, i.e., corynebacterium ulcerans and corynebacterium pseudotuberculosis although the reports from other parts of the world are limited (Zakikhany \& Efstratiou, 2012). In East Java, the incidence of diphtheria increases significantly from 2011 to today. The clinicians have been aware of this fact since 2005. One of the primary prevalence in East Java is in Bangkalan district. The incidence in East Java Province is the highest in Indonesia. At the same period, Indonesia was in the second rank in the world, after India (Hughes et al., 2015; WHO, 2015). The peak in East Java occured in 2012 with 955 cases where 37 patients deceased. All of 38 districts in the province reported the cases but the predominant area was in the northern and eastern parts (Husada et al., 2018). Many parties attempt to solve the problems simultaneously until nowadays. However, we cannot stop the outbreak altogether. The primary cause of the high number of diphtheria cases is the low immunological status in the community (Nanthavong et al., 2015; Wanlapakorn, Yoocharoen, Tharmaphornpilas, Theamboonlers, \& Poovorawan, 2014; Zasada, 2015). Many studies during diphtheria outbreaks in many countries showed the same reasons (Allam et al., 2016; Griffith et al., 2019; Meera \& Rajarao, 2014) The immunological data in the community in Indonesia, including East Java, is minimum (Hughes et al., 2015).

A collaborative team from the United Kingdom and Indonesia published a report in 2015 explaining the measurement of antidiphtheria antibodies in children ages 1 to 15 -year-old in two districts, Bangkalan and Kediri (Hughes et al., 2015). The studies on the older group have not been done in this province. The increasing trend of the mean age of the infectious disease's patients, including diphtheria, has been noted in many countries as well as in Indonesia. The susceptibility to diphtheria was caused by the low coverage of immunization and the weaning of the immunity by their age (Husada et al., 2017; Murhekar, 2017). Bangkalan and Kediri districts have very different immunization coverage and the number of cases (Hughes et al., 2015). Bangkalan is one of the leading districts for diphtheria, in term of the number of cases and carriers. Kediri, on the other side, is one of the best districts in East 
Java. The diphtheria patients from Kediri is almost zero.

The best effort to raise the immunological level is through immunization (Gunardi et al., 2018; Zasada, 2015). The main reason why diphtheria has almost vanished from the developed countries is because of the high number of immunization coverage (Zasada, 2015). This study aimed to analyze the antidiphtheria antibodies status among adolescents age 16 to 18 years old at Bangkalan and Kediri districts.

\section{METHODS}

This cross sectional study was performed between 1 August 2015 until 31 March 2016 at two districts, which is Bangkalan and Kediri. The fieldwork collected the samples in September until November 2015. The following regulation from the local District Educational Office, the collected samples were only from eleven grade of senior high schools (SMA). The students from ten and twelve grade were not allowed to participate because of the social and political situation.

The minimal sample size, based on the formula for two proportions hypothesis test with $\mathrm{p}=0.83$ (based on the data from Bangkalan and Kediri), were 54 and 78 students. Simple random sampling technique was used. The student numbers were identified and they were selected randomly one by one as target samples. There were nine senior high schools in Bangkalan with 2,457 students of eleven grades. There were 14 senior high schools in Kediri with 3,572 students at the same class.

The inclusion criteria included being 16-18years-old, at eleven grades of the school, and their parents or guardians signed the informed consent form. The exclusion criteria were students with severe diseases such as immunocompromised state, with heart problems, and those with the history of diphtheria disease. The data of former diphtheria patients were collected from the East Java Provincial Health Office.

Every parent or guardian also filled the questionnaire, which mainly asked the immunization state of the students. The next step was an interview with the students. The antibodies examination took $3 \mathrm{ml}$ of blood. The immunological states were divided into three categories i.e. never been immunized, less than three times immunization, and three times or more immunization.

The blood samples were brought to the Central Health Laboratory (BBLK) Surabaya. The laboratory method used the Vero cell. This method was a microcell culture neutralization test using titration of the antitoxin in the serum samples. The next step was to determine spectrophotometrically the equivalent point between toxin and antitoxin. The computer then would analyze the absorption value. The Vero cell method is the standard method of the World Health Organization (WHO, 2013).

The antidiphtheria antibodies level was evaluated based on the WHO standard which divide it into four levels: < $0.01 \mathrm{IU} / \mathrm{ml}$ (susceptible), $0.01-0.09 \mathrm{IU} / \mathrm{ml}$ (basic), $0.10-$ $1,00 \mathrm{IU} / \mathrm{ml}$ (full protection), and $>1 \mathrm{IU} / \mathrm{ml}$ (long term) (Scheifele \& Ochnio, 2009). Further analysis was also performed by dividing the antibodies level into two groups only, relatively immune $(\geq$ $0.10 \mathrm{IU} / \mathrm{ml})$ and susceptible $(<0.10 \mathrm{IU} / \mathrm{ml})$.

This study has received ethical approval as a part of a big study analyzing the genetic and clinical aspects of diphtheria during the outbreak in East Java. The certificate was granted from The Health Research Ethical Committee of Dr. Soetomo Academic General Hospital (number 383/Panke.KKE/VII/2015). The permission was also given by the National and Political Unions of East Java Province, and both of the leaders of the District Health Offices (Bangkalan and Kediri).

\section{RESULTS}

\section{Characteristics of the Samples}

The Demographic characteristic was listed in Table 1. There were significant differences in the sexual distribution of the subjects, parental ethnicity, and the paternal and maternal education. The majority of the subjects in Kediri were boys. The majority age was 16 years old in both districts. In terms of parental ethnicity, based on the location, Bangkalan District was predominated by Madurese while Kediri was predominated by Javanese. The parental education level was significantly lower in Bangkalan (Table 1).

\section{Immunization Data}

The immunization coverage in Kediri district, from newborns to finished elementary school, was higher than in Bangkalan. The BCG coverage in Kediri and Bangkalan amounted to 87 and $41.60 \%$, respectively. The similar results were indicated for other immunization as well. The coverage for the fifth dose of diphtheria vaccine, which usually given at the 1 st grade of elementary school was almost similar for both districts. At the elementary school, which can be the 6th and 7th 
diphtheria immunization, or other additional immunization during the outbreak era since 2011 have frequently given at Bangkalan. Immunization after elementary school is not a regular government policy, and usually be given only in particular circumstances. Kediri is not the main area of diphtheria outbreak, so the students at this district were never or rarely received the additional diphtheria vaccine (Table 2).

\section{Antidiphtheria Antibodies Level}

There were differences between the antibodies level in Bangkalan and Kediri districts based on the two classification models of WHO standard. There were more adolescents with higher antibodies level in Bangkalan than Kediri (Table $3)$.

\section{DISCUSSION}

The antidiphtheria antibodies level in the community is one of the critical elements in the effort to tackle the outbreak. There was a strong relationship between that level and the diphtheria outbreak anywhere in the world. The high or low frequency of immunization received by a child does not always mean a high or low level of immunity. Several factors also play significant roles (Hughes et al., 2015; Zasada, 2015). In general, someone will get immunity against one disease or microorganism if he or she receives the vaccine, contacts with the bacteria for many times, or has the history of being ill by certain bacteria (Hughes et al., 2015; Weinberger et al., 2013).

Table 1

Demography Characteristics of Respondents in Bangkalan and Kediri Districts

\begin{tabular}{|c|c|c|c|c|}
\hline \multirow{2}{*}{ Demography Characteristics of Respondents } & \multicolumn{2}{|c|}{ Bangkalan } & \multicolumn{2}{|c|}{ Kediri } \\
\hline & $\mathrm{n}$ & $\%$ & $\mathrm{n}$ & $\%$ \\
\hline \multicolumn{5}{|l|}{ Sex } \\
\hline Boys & 44 & 49.40 & 73 & 63.50 \\
\hline Girls & 45 & 50.60 & 42 & 36.50 \\
\hline \multicolumn{5}{|l|}{ Age (years) } \\
\hline 16 & 48 & 53.90 & 72 & 62.60 \\
\hline 17 & 35 & 39.30 & 39 & 33.90 \\
\hline 18 & 6 & 6.70 & 4 & 3.50 \\
\hline \multicolumn{5}{|l|}{ Paternal Ethnicity } \\
\hline Madurese & 83 & 93.30 & 0 & 0.00 \\
\hline Non-Madurese & 6 & 6.70 & 115 & 100.00 \\
\hline \multicolumn{5}{|l|}{ Maternal Ethnicity } \\
\hline Madurese & 81 & 91.00 & 0 & 0.00 \\
\hline Non-Madurese & 8 & 9.00 & 115 & 100.00 \\
\hline \multicolumn{5}{|l|}{ Highest Paternal Education } \\
\hline No formal education & 4 & 4.50 & 0 & 0.00 \\
\hline Elementary School (dropout) & 3 & 3.40 & 1 & 0.90 \\
\hline Elementary School (graduate) & 34 & 3.82 & 34 & 29.60 \\
\hline Junior High School (graduate) & 14 & 15.70 & 14 & 12.20 \\
\hline Senior High School (graduate) & 18 & 20.20 & 51 & 44.30 \\
\hline University/Academy & 16 & 18.00 & 15 & 13.00 \\
\hline \multicolumn{5}{|l|}{ Highest Maternal Education } \\
\hline No formal education & 6 & 6.70 & 0 & 0.00 \\
\hline Elementary School (dropout) & 3 & 3.40 & 0 & 0.00 \\
\hline Elementary School (graduate) & 43 & 48.30 & 34 & 29.60 \\
\hline Junior High School (graduate) & 12 & 13.50 & 20 & 17.40 \\
\hline Senior High School (graduate) & 14 & 15.70 & 52 & 4.20 \\
\hline University/Academy & 11 & 12.40 & 9 & 7.80 \\
\hline \multicolumn{5}{|l|}{ BCG scar } \\
\hline Yes & 44 & 49.40 & 95 & 82.60 \\
\hline No & 45 & 50.60 & 20 & 17.40 \\
\hline Total & 89 & 100.00 & 115 & 100.00 \\
\hline
\end{tabular}


Table 2

Immunization History of Respondents in Bangkalan and Kediri Districts

\begin{tabular}{|c|c|c|c|c|}
\hline \multirow{2}{*}{ Immunization History of Respondents } & \multicolumn{2}{|c|}{ Bangkalan } & \multicolumn{2}{|c|}{ Kediri } \\
\hline & $\mathrm{n}$ & $\%$ & $\mathrm{n}$ & $\%$ \\
\hline \multicolumn{5}{|l|}{$\begin{array}{l}\text { Basic Immunization (Less than 1-year-old, The Government } \\
\text { Scheme) }\end{array}$} \\
\hline Complete & 37 & 41.60 & 100 & 87.00 \\
\hline Incomplete & 31 & 34.80 & 12 & 10.40 \\
\hline Never & 21 & 23.60 & 3 & 2.60 \\
\hline \multicolumn{5}{|l|}{ Additional Diphtheria Immunization until Pre-School } \\
\hline At least once & 58 & 65.20 & 60 & 48.70 \\
\hline Never & 31 & 34.80 & 55 & 47.80 \\
\hline \multicolumn{5}{|l|}{ Diphtheria Immunization at the Elementary School } \\
\hline Yes & 48 & 53.90 & 56 & 48.70 \\
\hline No & 41 & 46.10 & 59 & 51.30 \\
\hline \multicolumn{5}{|l|}{ Diphtheria Immunization at the Junior High School } \\
\hline Yes & 50 & 56.20 & 3 & 2.60 \\
\hline No & 39 & 43.80 & 112 & 97.40 \\
\hline \multicolumn{5}{|l|}{ Total Diphtheria Immunization } \\
\hline At least 3 times & 51 & 57.30 & 106 & 92.20 \\
\hline More than 3 times & 38 & 42.70 & 9 & 7.80 \\
\hline Total & 89 & 100.00 & 115 & 100.00 \\
\hline
\end{tabular}

Table 3

Antidiphtheria Antibodies Level in Bangkalan and Kediri Districts

\begin{tabular}{|c|c|c|c|c|}
\hline \multirow{2}{*}{ The Immunity of Respondent } & \multicolumn{2}{|c|}{ Bangkalan } & \multicolumn{2}{|c|}{ Kediri } \\
\hline & $\mathrm{n}$ & $\%$ & $\mathrm{n}$ & $\%$ \\
\hline \multicolumn{5}{|l|}{ Antidiphtheria Antibodies Level (IU/ml) } \\
\hline Susceptible $(<0.01)$ & 2 & 2.20 & 15 & 13.00 \\
\hline $\operatorname{Basic}(0,01-0.09)$ & 6 & 6.70 & 49 & 42.60 \\
\hline Full $(0,10-1.00)$ & 30 & 33.70 & 41 & 35.70 \\
\hline Long Term $(>1.00)$ & 51 & 57.30 & 10 & 8.70 \\
\hline \multicolumn{5}{|l|}{ Immunity State } \\
\hline Relatively Immune (Full + Long Term) & 81 & 91.00 & 51 & 44.30 \\
\hline Susceptible (Susceptible + Basic) & 8 & 9.00 & 64 & 55.70 \\
\hline Total & 89 & 100.00 & 115 & 100.00 \\
\hline
\end{tabular}

Those who misery will not increase antibody levels against diphtheria. The most common way to get immunity against diphtheria is by immunization or frequent contact with toxicory Corynebacterium diphtheriae. Those who were infected by $C$. diphtheriae will show some level of the antibodies for a short time only. The previous study at Bangkalan and Kediri districts showed the level of antidiphtheria antibodies in children age 15-year-old or younger. The mean level of these antibodies in Kediri was higher than those in Bangkalan for the younger age group. This mean level tends to decrease over time, meaning that children over 10 years old In Bangkalan have higher mean level of antibodies (Hughes et al., 2015).

\section{The Characteristics of Respondents}

There were differences between parental ethnicity and education level. Bangkalan and Kediri are different in term of geographical and socio-cultural aspects. Bangkalan is in Madura Island, so the majority of respondents were Madurese. Kediri, on the other hand, is in the middle of East Java Province, and the majority of respondents were Javanese people. Many studies reported the association between ethnicity and the successfulness of immunization and other health programs. The same vaccine or immunization program will show very different results at the different ethnic groups or societies (Forster et al., 2017; Lakew, Bekele, \& Biadgilign, 2015). The coverage of immunization in Laos among Hmong, Laolum, and Khamou ethnic groups are very 
different (Nanthavong et al., 2015). This ethnicity factor plays a role in the difference of immunization coverage in Bangkalan and Kediri.

Parental education is also a very important decisive factor in health or medical-related programs. Some previous studies heavily highlight maternal education because the mothers usually take care of children and spend more time to be with their children in daily basis. The role of mothers was considered more important than fathers (Hudhah \& Hidajah, 2017; Rachman, Handayani, \& Ridwan, 2015; Vonasek et al., 2016) Some other studies in Indonesia revealed the contrast results. The role of fathers in some communities was more important than mothers, even when the education and income level of the mothers were better (Herliana \& Douiri, 2017; Holipah, Maharani, \& Kuroda, 2018; Jayanti, Sulaeman, \& Pamungkasari, 2017). The role of fathers was also determined by several aspects, such as the education level (Herliana \& Douiri, 2017). The parental education level was higher in Kediri. Presumably, this was an important factor in immunization. Many studies regarding immunization in many areas of Indonesia proved the correlation between immunization program and parental education level (Gunardi et al., 2018).

\section{Immunization Data}

In Indonesia, diphtheria vaccine was given at least 7 times, at the age of 2 months until 12 or 13 years (while the children were on the last levels of elementary school) (Gunardi et al., 2018). Three times diphtheria vaccine during the infant period should not be enough to maintain the antibodies level for such a long time (Gunardi et al., 2018; Li et al., 2015). This study showed that the coverage of governmental infant immunization in Kediri was excellent. This result was similar to the one from the previous study. Kediri is one of the best districts in East Java Province in the immunization coverage accomplishment (Hughes et al., 2015; Husada et al., 2017). Immunization during the junior high school period is not a routine government program, but during the diphtheria outbreak in East Java, the East Java Provincial Health Office performed six times of additional Outbreak Response Immunization (ORI). Three of them were done at 2013-2014 and the rest three in 2018. The first three ORI only covered 19 heavily impacted districts that including all Madura Island and the northern and eastern part of East Java. Those areas were called traditionally as "the horseshoe area" based on the figure at the map. Kediri was not included in this area. The second three Ori in 2018 were performed in the whole area of East Java Province (38 districts) (Husada et al., 2018). This data made a significant difference in the history of immunization between students at both districts.

\section{Antidiphtheria Antibody Level}

Bangkalan has more adolescents with a high level of antibodies. The previous study revealed the higher anti diphtheria antibodies level in Kediri only until 6th grade of elementary school. After that age, the antidiphtheria antibodies level was higher in Bangkalan and should last for a long time. This study is in accordance with the previous one. At the age of 16-18 years of age, the adolescents in Bangkalan showed higher antibodies levels. Once again, the antibodies against diphtheria were the results of immunization and frequent contacts with the bacteria. For areas with the low level of immunization coverage, high level of antibodies was the result of those natural exposures against the toxigenic C. diphtheriae (Hughes et al., 2015). This is the main reason for the high level of antibodies among adolescents at Bangkalan.

The incidence of diphtheria cases and carriers in Bangkalan were far higher. The results of the nasal and throat microbiological cultures from the study by Hughes et al. in 2015 proved it. Indirectly, this also revealed the high number of circulating toxigenic $C$. diphtheriae in the community in Bangkalan (Hughes et al., 2015). The exposure of these bacteria against adolescents was intense and subsequently raised the antibodies level.

Higher level and longer-lasting antibodies as the results of natural exposure against the bacteria was not a good thing. This bacterium is very dangerous and can cause death for many people all over the world. In some infection, those who survived after the infection and live will show the high antibodies level. Higher antibodies because of immunization, certainly, is a much better thing (Hughes et al., 2015; Husada et al., 2018). The number of circulating bacteria in Kediri was less. This was also proven by the low number of diphtheria cases and carriers. The immunity of children and adolescents in Kediri were the results of immunization (Hughes et al., 2015). For many cases, it is true that the immunity from immunization was not as good as the immunity from natural exposure. That is why people need repeated immunization after some certain time (Fadlyana et al., 2016). Immunity, as a result of natural exposure, will also last longer (Gunardi et 
al., 2018). The booster can boost the decreasing antibodies, so this booster is very crucial. Diphtheria immunization in many countries was boosted every 10 years, especially for special groups like health and medical officers. The Ministry of Health in Indonesia suggests the health personnel in this country to receive the decennial booster (Gunardi et al., 2018; Li et al., 2015).

\section{Research Limitations}

There were two limitations to this study. First, only very few parents kept the immunization records (mostly by Kartu Menuju Sehat or KMS). Second, the study only covered public high schools and not private schools. The immunization record at the village midwife was not found, mostly because of the extended distance between the infant age and adolescents. KMS and the records at the village midwife are the official and valid records as the evidence of immunization activities, should they be available. The parental memory is another source of evidence, but it is well known already that this memory is less valid (Hughes et al., 2015; Nanthavong et al., 2015). Any forms of notes or records are important elements in a successful immunization program (Osaki \& Aiga, 2019).

The samples in this study could not represent the whole adolescents in both districts. Many children and adolescents join private schools because of the capacity limitation of the public schools. Another enormous and highly significant group of children and adolescents are enrolled to Islamic boarding schools or pesantren. Several studies already proved the role of pesantren in relation with immunization and the transmission of some infectious diseases (Haque et al., 2017; Putri, Wibowo, \& Nugraheni, 2016; Sumarni \& Susanna, 2014).

\section{CONCLUSION}

Adolescents aged 16-18 years with high immunity of diphtheria were more in Bangkalan than those of Kediri. This age group does not receive any routine diphtheria immunization any longer. If there is no other method to keep the antidiphteria level, those antibodies will gradually decrease. The low level of antidiphtheria antibodies in Kediri has made adolescents in Kediri more susceptible to diphtheria. This factor should also be one of the considerations for traveling to certain areas with a high number of circulating toxigenic $C$. diphtheriae.
The data from Kediri indicates the importance of not only routine immunization but also booster immunization. This finding becomes a suggestion to the local government in Kediri, especially during the outbreak period of diphtheria in East Java Province.

\section{ACKNOWLEDGMENTS}

The authors would like to express their gratitude to the teams from the District Health Office and District Education Office at Bangkalan and Kediri, all of the headmasters of the participating senior high schools. Most importantly, the author would like to thank all the respondents and their parents or guardians. This study also received partial funding from the Faculty of Medicine, Universitas Airlangga, Surabaya

\section{REFERENCES}

Allam, R. R., Uthappa, C. K., Duerst, R., Sorley, E., Udaragudi, P. R., Kampa, S., \& Dworkin, M. S. (2016). A case-control study of diphtheria in the high incidence city of Hyderabad, India. Pediatric Infectious Disease Journal, 35(3), 253-256.

Fadlyana, E., Rusmil, K., Garna, H., Sumarman, I., Adi, S. S., \& Bachtiar, N. S. (2016). Imunogenisitas dan keamanan vaksin tetanus difteri (Td) pada remaja sebagai salah satu upaya mencegah reemerging disease di Indonesia. Sari Pediatri, 15(3), 141. https://doi.org/10.14238/sp15.3.2013.141-9

Forster, A. S., Rockliffe, L., Chorley, A. J., Marlow, L. A. V., Bedford, H., Smith, S. G., \& Waller, J. (2017). Ethnicity-specific factors influencing childhood immunisation decisions among black and asian minority ethnic groups in the UK: a systematic review of qualitative research. Journal of Epidemiology and Community Health, 71(6), 544-549. https://doi.org/10.1136/jech-2016-207366

Griffith, J., Bozio, C. H., Poel, A. J., Fitzpatrick, K., DeBolt, C. A., Cassiday, P., ... Acosta, A. M. (2019). Imported toxin-producing cutaneous diphtheria - Minnesota, Washington, and New Mexico, 2015-2018. MMWR. Morbidity and Mortality Weekly Report, $\quad$ 68(12), 281-284. https://doi.org/10.15585/mmwr.mm6812a2

Gunardi, H., Rusmil, K., Fadlyana, E., Dhamayanti, M., Sekartini, R., Tarigan, R., ... Hadinegoro, S. R. S. (2018). DTwP-HB-Hib: 
antibody persistence after a primary series, immune response and safety after a booster dose in children 18-24 months old. BMC Pediatrics, $18(1), \quad 1-8$. https://doi.org/10.1186/s12887-018-1143-6

Haque, F., Sturm-Ramirez, K., Homaira, N., Gurley, E. S., Hossain, M. J., Hasan, S. M. M., ... Luby, S. P. (2017). Influenza B virus outbreak at a religious residential school for boys in Northern Bangladesh, 2011. Influenza and Other Respiratory Viruses, 11(2), 165169. https://doi.org/10.1111/irv.12430

Herliana, P., \& Douiri, A. (2017). Determinants of immunisation coverage of children aged 1259 months in Indonesia: a cross-sectional study. BMJ Open, 7(12), 1-14. https://doi.org/10.1136/bmjopen-2016015790

Holipah, Maharani, A., \& Kuroda, Y. (2018). Determinants of immunization status among 12- to 23-month-old children in Indonesia (2008-2013): a multilevel analysis. $B M C$ Public Health, 18(1), 1-11. https://doi.org/10.1186/s12889-018-5193-3

Hudhah, M., \& Hidajah, A. C. (2017). Mother's behavior in complete basic immunization at Gayam Community Health Center Sumenep Regency. Jurnal Promkes, 5(2), 167-180.

Hughes, G. J., Mikhail, A. F. W., Husada, D., Irawan, E., Kafatos, G., Bracebridge, S., ... Efstratiou, A. (2015). Seroprevalence and determinants of immunity to diphtheria for children living in two districts of contrasting incidence during an outbreak in East Java, Indonesia. Pediatric Infectious Disease Journal, 34(11), 1152-1156. https://doi.org/10.1097/INF.00000000000008 46

Husada, D., Primayani, D., Marbun, K., Kartina, L., Puspitasari, D., Tirthaningsih, N. W., ... Ismoedijanto. (2018). Risk factors in diphtheria carriers in Indonesian children. Southeast Asian Journal of Tropical Medical Public Health, 49(4), 660-669.

Husada, D., Puspitasari, D., Kartina, L., Setiono, P., Moedjito, I., \& Kartika, B. (2017). Six year surveillance of diphteria oubreak in Indonesia. Open Forum Infectious Diseases, 4(Supplement 1 ), 244. https://doi.org/10.1093/ofid/ofx163.523

Jayanti, N., Sulaeman, E. S., \& Pamungkasari, E. P. (2017). Effects of predisposing, enabling, and reinforcing factors on completeness of child immunization in Pamekasan, Madura. Journal of Epidemiology and Public Health,
2(2),

106-118.

https://doi.org/10.26911/jepublichealth.2017. 02.02 .02

Lakew, Y., Bekele, A., \& Biadgilign, S. (2015). Factors influencing full immunization coverage among 12-23 months of age children in Ethiopia: evidence from the national demographic and health survey in 2011. BMC Public Health, 15(1), 1-8. https://doi.org/10.1186/s12889-015-2078-6

Li, X., Chen, M., Zhang, T., Li, J., Zeng, Y., \& Lu, L. (2015). Seroepidemiology of diphtheria and pertussis in Beijing, China: a crosssectional study. Human Vaccines and Immunotherapeutics, 11(10), 2434-2439. https://doi.org/10.1080/21645515.2015.10629 54

Meera, M., \& Rajarao, M. (2014). Diphtheria in Andhra Pradesh-a clinical-epidemiological study. International Journal of Infectious Diseases, $\quad 19(1), \quad 74-78$. https://doi.org/10.1016/j.ijid.2013.10.017

Murhekar, M. (2017). Epidemiology of diphtheria in India, 1996-2016: implications for prevention and control. American Journal of Tropical Medicine and Hygiene, 97(2), 313318. https://doi.org/10.4269/ajtmh.17-0047

Nanthavong, N., Black, A. P., Nouanthong, P., Souvannaso, C., Vilivong, K., Muller, C. P., ... Buisson, Y. (2015). Diphtheria in Lao PDR: insufficient coverage or ineffective vaccine? PLoS ONE, 10(4), 1-14. https://doi.org/10.1371/journal.pone.0121749

Osaki, K., \& Aiga, H. (2019). Adapting homebased records for maternal and child health to users' capacities. Bulletin of the World Health Organization, 97(4), 296-305. https://doi.org/10.2471/BLT.18.216119

Putri, I. P. N., Wibowo, D. A., \& Nugraheni, A. (2016). Perilaku pencegahan skabies di Pondok Pesantren Darut Taqwa Bulusan Semarang tahun 2016. Jurnal Kedokteran Diponegoro, 5(4), 1064-1073.

Rachman, I., Handayani, M., \& Ridwan, M. (2015). Pengetahuan, sikap ibu dan peran petugas kesehatan sebagai faktor dalam meningkatkan cakupan imunisasi hepatitis B di Kota Jambi. Media Kesehatan Masyarakat Indonesia, 11(1), 32-38.

Sumarni, I., \& Susanna, D. (2014). Boarding school environment health conditions and personal hygiene students with hepatitis incident. Jurnal Kesehatan Masyarakat Nasional, 9(2), 179-186. 
Vonasek, B. J., Bajunirwe, F., Jacobson, L. E., Twesigye, L., Dahm, J., Grant, M. J., ... Conway, J. H. (2016). Do maternal knowledge and attitudes towards childhood immunizations in rural Uganda correlate with complete childhood vaccination? PLoS ONE, 11(2), $1-16$. https://doi.org/10.1371/journal.pone.0150131

Wanlapakorn, N., Yoocharoen, P., Tharmaphornpilas, P., Theamboonlers, A., \& Poovorawan, Y. (2014). Diphtheria outbreak in Thailand, 2012; seroprevalence of diphtheria antibodies among Thai adults and its implications for immunization programs. The Southeast Asian Journal of Tropical Medicine and Public Health, 45(5), 11321141.

Weinberger, B., Schirmer, M., Gothe, R. M., Siebert, U., Fuchs, D., \& GrubeckLoebenstein, B. (2013). Recall responses to tetanus and diphtheria vaccination are frequently insufficient in elderly persons. PLoS ONE, 8(12), 1-12. https://doi.org/10.1371/journal.pone.0082967

WHO. (2013). Manual for quality control of diphtheria, tetanus and pertussis vaccines. Geneva: World Health Organization. Retrieved January, 28, 2019 from https://apps.who.int/iris/handle/10665/80681

WHO. (2015). Diphtheria reported cases. World Health Organization. Geneva.

Zakikhany, K., \& Efstratiou, A. (2012). Diphtheria in Europe: Current problems and new challenges. Future Microbiology, 7(5), 595607. https://doi.org/10.2217/fmb.12.24

Zasada, A. A. (2015). Corynebacterium diphtheriae infections currently and in the past. Przeglad Epidemiologiczny, 69(3), 439444. 